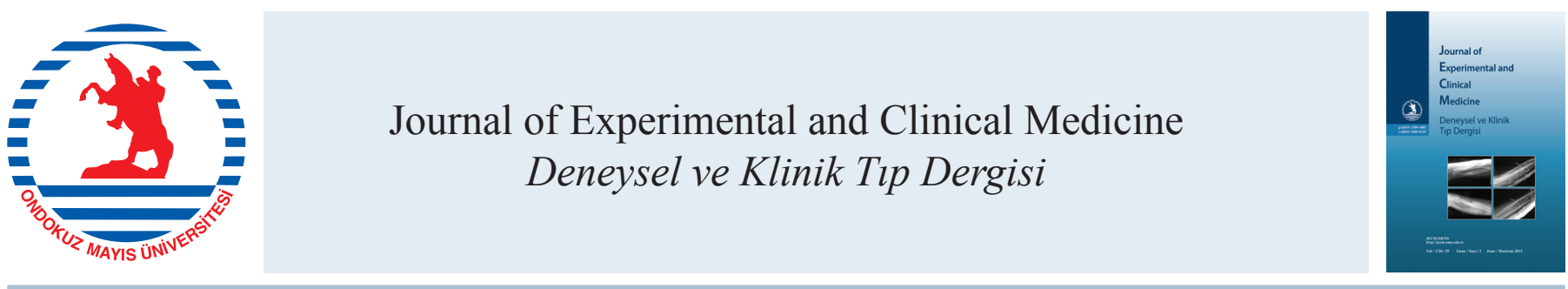

Derleme / Review

doi: $10.5835 /$ jecm.omu.29.02.003

\title{
Endoplazmik retikulum stresi ve katlanmamış protein cevabı
}

\section{Endoplasmic reticulum stress and unfolded protein response}

\author{
Aynur Düzgüna, Hasan Alaçam*b, Ali Okuyucu ${ }^{\text {b }}$ \\ ${ }^{a}$ Tirebolu Devlet Hastanesi, Giresun, Türkiye \\ ${ }^{b}$ Ondokuz Mayıs Üniversitesi Tıp Fakültesi, Tıbbi Biyokimya Anabilim Dalı, Samsun, Türkiye
}

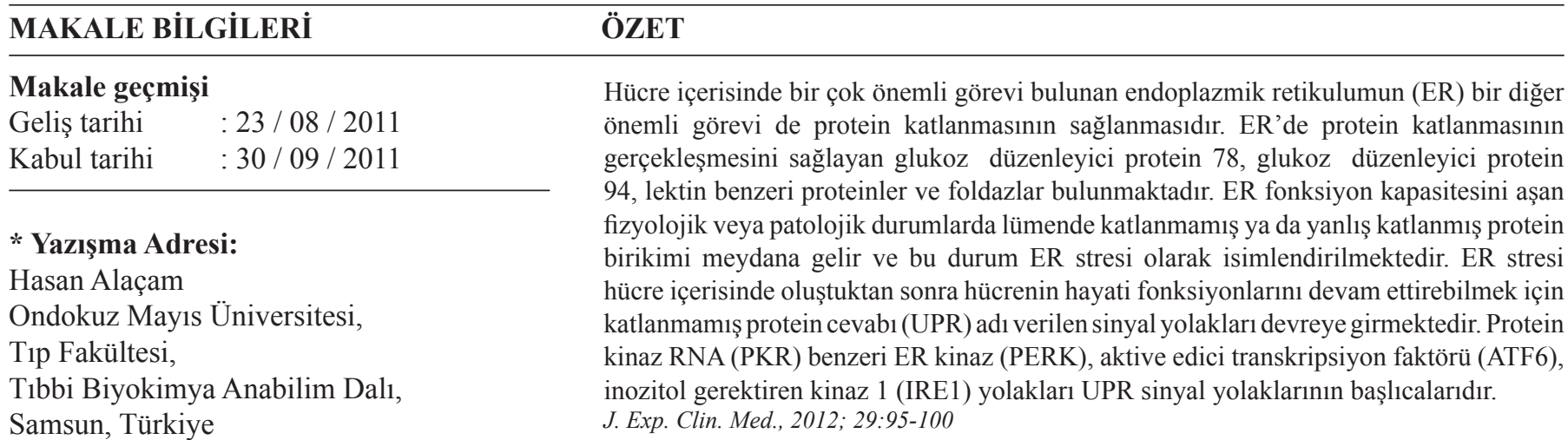

e-posta: hasanalacam@hotmail.com

Anahtar Kelimeler:

Endoplazmik retikulum

Grp78

Grp94

PERK

ATF6

IRE1

\section{Key words:}

Endoplasmic reticulum

Grp78

Grp94

PERK

ATF6

IRE1

\begin{abstract}
Another important function of the endoplasmic reticulum (ER), which has many important tasks in the cell, is to ensure the protein folding. In ER, there are glucose regulated protein 78 , glucose regulated protein 94 , lectin like proteins and foldases, which enable the protein folding. In case of physiological and pathological situations that exceed the function capacity of ER, unfolded or misfolded protein accumulation occurs in lumen and this case is named as ER stress. After the ER stress occurs in the cell, the signal pathways named unfolded protein response (UPR) step in for the continuance of the vital functions of the cell. Major UPR signal pathways include protein kinase RNA (PKR) like ER kinase (PERK), activating transcription factor 6 (ATF6), j requiring kinase 1 (IRE1). J. Exp. Clin. Med., 2012; 29:95-100
\end{abstract}

\section{Endoplazmik retikulum fonksiyonları}

Endoplazmik retikulum (ER) ökaryotlarda protein katlanmasının düzenlendiği en önemli organeldir. Kompleks yapıdaki proteinler ER'de katlanırken sitoplazmada daha basit yapıdaki proteinler katlanır (Dobson ve ark., 1998). Endoplazmik retikuluma gelen yeni sentezlenmiş protein çeşitli modifikasyonlara uğramadan katlanamaz. Bu bağlamda posttranslasyonel modifikasyonların çoğu (N glikozilasyon, disülfid oluşumu, hidroksilasyon, oligomerizasyon) ER'de meydana gelir (Tu ve ark., 2000).

Glikozilasyon, proteine hidrofilik özellik kazandırarak proteinin sudaki çözünürlüğünü arttırır. Ayrıca oligosakkaritin sağladığı özellikler sayesinde proteinin etrafını çevreleyen proteinlerle ilişkisi engellenir ve oligosakkarit bir nevi şaperon olarak görev yapmış olur (Schroder ve Kaufman, 2005). Oligosakkarit peptid omurgayla etkileşerek yapının stabil olmasını sağlar. Şeker rezidülerinin ardışık eklenmeleri lektin mekanizması ile kontrol edilerek proteinin katlanması takip 
edilir. Bu da bir çeşit kalite kontrol olarak değerlendirilebilir (Ellgaard ve ark., 1999; Stevens ve Argon, 1999; Wormald ve Dwek, 1999). ER, protein sentezi için kalite kontrol merkezi olarak tanımlanabilir. Protein katlanmasının doğru olup olmadığı, yanlış katlanma oldu ise düzeltilmesi, eğer düzeltilemezse yanlış katlanan proteinlerin yıkıma gönderilmesi ER'nin görevleridir (Horwich, 2002; Schroder ve Kaufman, 2005).

ER'de proteinlerin doğru katlanmasına yardımcı olan şaperon adı verilen moleküller bulunmaktadır. Protein katlanmasına yardımcı olan bu moleküller aynı zamanda iyi birer kalsiyum tamponlayıcı proteinlerdir ve aktiviteleri için de kalsiyuma ihtiyaç duymaktadırlar (Buck ve ark., 2007).

ER fonksiyon kapasitesini aşan fizyolojik veya patolojik durumlarda lümende katlanmamış ya da yanlış katlanmış protein birikimi meydana gelir ve bu durum ER stres olarak isimlendirilmektedir (Rutkowski ve Kaufman, 2004). ER stresi oluştuktan sonra, hücrede homeostazı tekrar sağlamak ve stresten en az zararla kurtulmak için katlanmamış protein cevabı (UPR) adı verilen ve bir takım hücre içi sinyal yolaklarından oluşan olaylar dizisi aktiflenmektedir. UPR ile öncelikle hücre yaşamının devamı sağlanmaya çalışılır (Kaufman, 2002; Lee, 2007).

\section{Protein katlanmasında rol oynayan moleküller}

Glukozla düzenlenen protein 78 (Grp78) monomerik veya dimerik formdadır ve $78 \mathrm{kDa}$ 'dur. Oligomerik form depo şeklidir. Monomerik formu ise şaperon görevi görmektedir. Grp78, ER dışında nukleus ve mitokondride de bulunmaktadır (Little ve ark., 1994; Hendershot, 2004; Wang ve ark., 2009). Proteinin ER'a translokasyonunun düzenlenmesi, protein katlanmasının sağlanması, kalsiyum bağlanması, apopitozisin düzenlenmesi, UPR cevabının düzenlenmesi, protein kalite kontrolünün sağlanması, protein yıkımlanmasının sağlanması Grp78'in UPR ile ilgili başlıca görevleridir.

ER'de kalsiyum miktarının azalması ve glikozillenmemiş proteinlerin birikmesi gibi stres durumlarında hücre yaşamının sürdürülmesinde Grp78 kritik rol oynamaktadır (Misra ve ark., 2006; Lee, 2007). UPR dışında embriyolojik gelişimde, kanserin ilerlemesinde, ilaç direncinde rol almaktadır (Fernandez ve ark., 2000; Reddy ve ark., 2003; Lee ve ark., 2006).

Protein katlanmasından sorumlu bir diğer protein olan glukozla düzenlenen protein 94 (Grp94) dimerik bir proteindir ve $94 \mathrm{kDa}$ ağırlığındadır. ER'de en fazla bulunan proteindir (Little ve ark., 1994; Argon ve Simen, 1999). Protein katlanmasının sağlanması ve eğer katlanamayan proteinler varsa yıkıma gönderilmesi Grp94'ün başlıca görevleridir. Bunların dışında ayrıca kalsiyum bağlanması, apoptozisin düzenlenmesi, immünite (antijen sunumu) gibi hücre içi olaylarda rol alır.

Kalneksin ve kalretikulin, glikoproteinlerin kalite kontrolünden sorumludur. Glikoproteinlere bağlanan kalneksin ve kalretikulin, disülfit izomerazlar ve foldazlar için substrat sunar. Sonuçta proteinin tersiyer yapısı şekillenmiş olur (Wormald ve Dwek, 1999). Ayrıca, UDPglukoz; glikoprotein glikoziltransferaz (UGGT) ile tekrar glikozillenme kalneksinle iletişimi sağlayarak ER degradation enhancing $\alpha$-annosidase-like protein (EDEM)'eyönlenmesine aracılık eder (Maattanen ve ark., 2010). Olgunlaşmamış protein endoplazmik retikuluma girdiği zaman N-bağlı glikanlarla (iki N-asetilglukozamin, dokuz mannoz ve üç glukoz molekülünden oluşur) modifiye edilir. Protein doğru katlanmışsa son glukozun uzaklaştırılması ile şaperonların bağlandığı bölge ortadan kaldırılarak olgun proteinin golgiye transferi gerçekleşir. Ancak protein doğru katlanamamışsa UGGT katlanmamış kısma bağlanır ve deglikozile glikana glukoz ekler. Dolayısıyla kalneksin, kalretikulin için bağlanma bölgesi oluşturulur. Bu zaman zarfında doğru konformasyon sağlanmışsa UGGT tekrar aktive olmaz ve protein golgiye gider. $\mathrm{Bu}$ durum sağlanamamışsa UGGT'nin rol aldığı sikluslar protein yıkım kararı çıkana kadar tekrarlanır (Corbett ve ark., 1999; Schroder ve Kaufman, 2005). Foldazlar, ER'de lokalize şaperon benzeri enzimlerdir. Disülfid bağ oluşumu, protein katlanması ve katlanmamış proteinlerin tanınmasında ve yıkımlanmaya gidişinde görev alırlar (Pollard ve ark., 1998; Sevier ve ark., 2001).

\section{Katlanmamış protein cevabı}

Bir hücrenin stresi hissetmesi, cevap vermesi ve stresi yenmesi homeostazın sağlanması için gereklidir. N-bağlı glikozilasyon inhibisyonu ve kalsiyum homeostazının bozulması, enfeksiyon, genetik mutasyon, besin eksikliği, hipoksi gibi ekzojen ya da endojen kaynaklı bir çok stres nedeni vardır (Lai ve ark., 2007; Kapoor ve Sanyal, 2009). Hücre, karşılaştığı ER stres ile baş edebilmek ve homeostazı sağlamak için UPR yolağını kullanır. ER, lümeninde biriken katlanamamış proteinlerin katlanmasını sağlamak için kapasitesini artırır. Katlanmaya destek olan yardımcı moleküllerin sentezi artırılır. Yanlış katlanan proteinler düzeltilemezse ER yükünü azaltmak için yıkıma gönderilir. Hücre yine de adaptasyonu sağlayamazsa çevre dokuya zarar vermemesi için apoptozise yönlendirilir (Conn ve ark., 2002).

Makrofaj, pankreas beta hücreleri gibi sekretuvar hücrelerin farklılanma ve hücre büyümesi yanlış katlanan protein üretimine neden olarak UPR'yi indükleyen fizyolojik durumlardır. Patolojik durumlar ise, hipoglisemi, hiperhomosisteinemi ve iskemi gibi artmış metabolik durumlar; sekretuvar ve transmembran proteinleri kodlayan genlerde mutasyon; hepatit C gibi enfeksiyonlardır (Lai ve ark., 2007). Günümüze kadar UPR sensörü olarak üç transmembran protein tanımlanmıştır (Mori, 2000; Ron ve Walter, 2007).

\section{A. Katlanmamış protein cevabı sinyal yolları a. Protein kinaz RNA (PKR) benzeri ER kinaz (PERK) sinyal yolu}

ER membranında lokalize, Tip I transmembran serin treonin kinazdır. Normal şartlar altında Grp78 ile beraber bulunması molekülün inaktif monomerik durumda kalmasını sağlar (Schroder ve Kaufman, 2005; Zhang ve Kaufman, 2008). ER kapasitesini aşan yükle veya stresle karşılaştığ zaman beraberinde bulunan Grp78 lümene katlanmaya yardımcı olması için gönderilirken PERK homodimerize olarak fosforillenir. Aktive olan PERK daha sonra ökaryotik başlama faktörü (eIF) $2 \alpha$ 'yı fosforiller. Fosforillenen eIF $2 \alpha$, genel translasyonu hücre içinde durdurur. Ancak bazı seçilmiş proteinlerin translasyonu devam eder ve miktarları artar (Kaufman, 2002). Translasyonun inhibe olması sonucu kısa ömürlü proteinler hücreden temizlenir. En tipik örnek siklin D'dir. ER stres sırasında bu proteinin yokluğu memeli hücrelerinin G1 fazında kalmasına yol açar (Harding ve ark., 1999; Kauf-man, 1999; Scheuner ve ark., 2001) (Şek. 1). 
eIF2 $\alpha$ 'ya ek olarak nuclear factor-erythroid 2-related factor 2'de (NRF2) PERK tarafindan fosforillenir. NRF2, normal şartlarda sitoplazmada keap1 ile kompleks halde ve inaktiftir. ER stres sonucu fosforillenen molekül kompleksinden ayrılır ve aktifleşir. Nukleusa giden aktif NRF2 antioksidan response elementle (ARE) etkileşir (Huang ve ark., 2001).

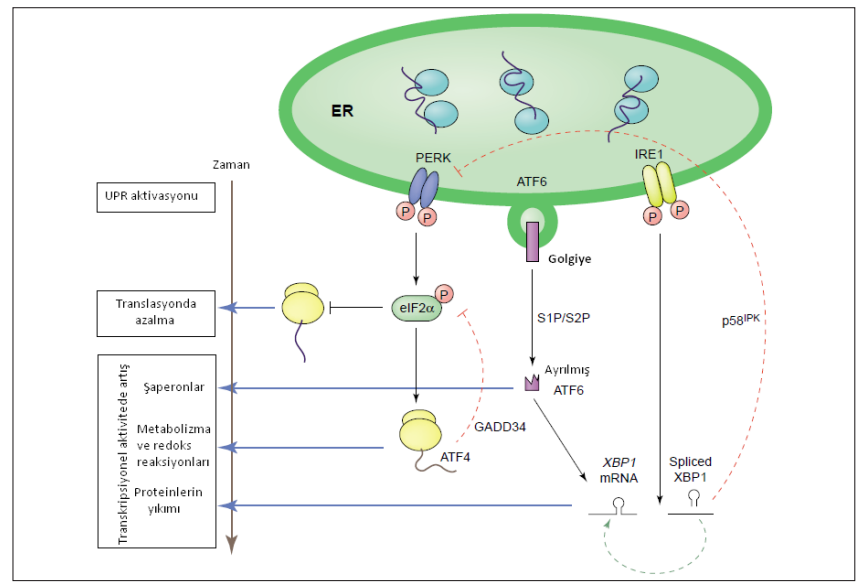

Şek. 1. UPR yolakları. Protein kinaz RNA (PKR) benzeri ER kinaz (PERK) yolağ1, aktive edici transkripsiyon faktörü 6 (ATF6) yolağ1 ve inozitol gerektiren kinaz 1 (IRE1) yolağı aktive olduktan sonra hücre içerisinde farklı aktivasyonlara neden olmaktadır (Rutkowski ve Kaufman, 2004) (Yayıncıdan kullanımı için izin alınmıştır).

\section{b. Aktive edici transkripsiyon faktörü 6 (ATF6) sinyal yolu}

ATF6, hücrede ER stresi olmadığında, ER membranında Grp78 ile beraber inaktif şekilde bulunmaktadır. ER stres ile karşılaşınca Grp78 lümene katlanmaya yardımcı olmak için gönderilirken ATF6'da posttranskripsiyonel modifikasyona uğrar. Golgiye gönderilen ATF6, site1 proteazla (S1) etkileşerek kırpılmaya uğrar. Daha sonra site2 proteaz (S2) tarafindan kırpılan ATF6 nukleusa gönderilir. Burada ER response elemente bağlanır. Grp78, Grp94 gibi ER şaperonlarının ekspresyonunu artırır. Sonuç olarak bu proteinlerin sentezi artar ve ER katlama kapasitesi yükselerek strese karşı korunma sağlanmaya çalışılır (Yoshida ve ark., 2001; Zhang ve Kaufman, 2008; Naidoo, 2009 ) (Şek. 1).

\section{c. Inositol gerektiren kinaz 1 (IRE1) sinyal yolu}

Transmembran proteindir. Sitoplazmik bölümü endoribonükleaz ve kinaz aktivitesine sahiptir. Lümene bakan bölümü PERK ile benzerdir ve dimerizasyon gösterir. İki formu vardır. IRE1- $\alpha$ tüm hücrelerde bulunurken $\beta$ formu ise barsaklarda bulunmaktadır (Ron, 2002).

IRE1, diğer UPR yolakları gibi Grp 78 ile beraberken inaktiftir. ER stres sirasinda Grp78'in ayrılmasıyla dimerize olur ve otofosforillenir. Aktif haldeki IRE1'in RNAaz aktivitesi ile mRNA X-box bağlayıcı protein 1 (XBP) den 26 nükleotid uzaklaştırılır ve oluşan kırpılmış XBP1 mRNA translasyona uğrayarak transkripsiyon faktörüne dönüşür. ER şaperonlarının ve katlanmaya yardımcı olan enzimlerin (PDI gibi) upregulasyonuna neden olur (Liu ve ark., 2000). XBP1 mRNA sitoplazmada normalde bulunmaktadır. Ancak kırpılmamış şekildedir (Calfon ve ark., 2002) (Şek. 1).

\section{B. Fizyolojik durumlarda UPR}

a. B hücre diferansiyasyonu ve katlanmamış protein cevabı

Monosit hücrelerinin plazma hücresine dönüşümü sırasında (B hücre diferansiyasyonu) sekretuvar yolaklar tekrar yapılandırılır, hücrenin görünümü değişir ve antikor sentez ve sekresyonu yeteneği kazandırılır. Bütün bu değişimler esnasında UPR yolakları ciddi şekilde aktive olmaktadir (Tablo 1).

\section{b. Pankreatik $\beta$ hücre fonksiyonu ve katlanmamış protein cevabı}

PERK pankreasta yüksek miktarda eksprese edilir. PERK-/- farelerde pankreatik disfonksiyona rastlanmıştır ve doğumdan hemen sonra diyabet gelişmiştir. İnsanlarda PERK genindeki mutasyon, insülin bağımlı diyabet, epifizyal displazi, büyüme retardasyonu ile karakterize WolcottRallison sendromuna neden olmaktadır (Delepine ve ark., 2000; Lai ve ark., 2007) (Tablo 1).

\section{Tablo 1. Fizyolojik durumlarla UPR ilişkisi}

\begin{tabular}{ll} 
Fizyolojik durum & UPR aktivasyonu \\
B hücre diferansiyasyonu & $\begin{array}{l}\text { Grp78, Grp94 ve CHOP ekspresyonu } \\
\text { indüklenir. IL-4 ile stimülasyon sonucunda }\end{array}$ \\
& IRE1 aktive olur, XBP1 mRNA hizlıca \\
& arttırllır ve yüksek miktarda immünglobin \\
& sentez edilir (Reimold ve ark., 2001; Gass \\
& ve ark., 2002; Iwakoshi ve ark., 2003; Lai \\
& ve ark., 2007). \\
Pankreas $\boldsymbol{\beta}$ hücre fonksiyonu & Glukoz seviyelerindeki azalma, PERK \\
& aktivasyonuna ve eIF2 $\alpha$ fosforilasyonuna \\
& neden olarak protein sentezini inhibe \\
& eder ve proinsülin mRNA translasyonu \\
& durur. Glukoz seviyesindeki artma PERK \\
& sinyalizasyonunu inaktive eder (Harding \\
& ve ark., 2001; Harding ve Ron, 2002). \\
\hline
\end{tabular}

\section{Patolojik durumlarda UPR}

a. UPR ve hiperhomosisteinemi

Homosistein, sekretuvar proteinlerin sistein aminoasitleri arasında istenmeyen disülfit bağları oluşturarak protein katlanmasını engellemektedir ve bu durum ER strese yol açmaktadır (Eikelboom ve ark., 1999; Zhang ve ark., 2001) (Tablo 2).

\section{b. UPR ve nörolojik hastalıklar}

UPR, değişik fizyolojik ve patolojik durumlarda ER'nin adaptasyon için kullandığı yolaktır. Endoplazmik retikulum kapasitesinden fazla yükle karşılaşır ve baş edemezse UPR aktive olur. Asıl amaç hücre yaşamının devam ettirilmesi için koruyucu mekanizmaların kullanılmasıdır (Schroder ve Kaufman, 2005; Kapoor ve Sanyal, 2009).

UPR yolaklarının aktiflenmesi sonucu elde edilen ilk cevap translasyonun durdurularak protein yükünün azaltılmasıdır (Kaufman, 1999). Bu arada şaperonların gen ekspresyonları da arttırılmaktadır (Ma ve Hendershot, 2004) ve katlanamayan proteinlerin ER'ye ek yük getirmemesi için proteinler yıkıma gönderilmektedir (Shen ve Zhang, 2004; Lai ve Teodoro, 2007) (Tablo 2).

Hücre karş1laştığ stresten kurtulamazsa çevre hücrelerin 


\begin{tabular}{|c|c|}
\hline Patolojik durum & UPR aktivasyonu \\
\hline Hiperhomosisteinemi & $\begin{array}{l}\text { UPR ile ilgili genlerden BIP, Grp94, CHOP ve } \\
\text { HERP ekspresyonlarında artış görülmektedir } \\
\text { (Qutinen ve ark., 1999). }\end{array}$ \\
\hline Serebral iskemi & $\begin{array}{l}\text { Geçici iskemi sonrası UPR genlerinin } \\
\text { mRNA miktarı artar ve protein sentezi büyük } \\
\text { oranda inhibe edilir ve bu inhibisyon eIF2 } \alpha \\
\text { fosforilasyonu ile yakın ilişkilidir (Bodsch } \\
\text { ve ark., 1985; Hu ve ark., 2001). }\end{array}$ \\
\hline Nörodejeneratif hastalıklar & $\begin{array}{l}\text { Alzheimer ve Parkinsonda etkilenen } \\
\text { nöronların çevresinde, nükleusunda ve } \\
\text { sitoplazmasında anormal protein agregatları } \\
\text { birikmektedir. Anormal protein birikimi UPR } \\
\text { ve hücre ölümü ile beraberdir (Thilmann ve } \\
\text { ark., 1986; Doutheil ve ark., 1999). }\end{array}$ \\
\hline Apopitozis & $\begin{array}{l}\text { PERK ve IRE1 aktive olduğunda Bcl-2 } \\
\text { proteininin ekspresyonunda ve aktivitesinde } \\
\text { değişikliğe yol açarak Bax ve Bak } \\
\text { proteinlerinin oligomerizasyonuna yol açar } \\
\text { ve mitokondri membran bütünlügünü bozar } \\
\text { (Nechushtan ve ark., 1999; Wei ve ark., } \\
\text { 2001). }\end{array}$ \\
\hline Diyabet & $\begin{array}{l}\text { Diyabette özellikle PERK sinyal yolağında } \\
\text { aktivite azalmas1 söz konusudur. Hem Tip1 } \\
\text { hem de Tip2 diyabette ER stres önemli rol } \\
\text { oynamaktadır (Harding ve ark., 2001). }\end{array}$ \\
\hline Hipoksi & $\begin{array}{l}\text { Hipoksi en önemeli UPR indükleyicilerinden } \\
\text { birisidir. Hipoksi PERK aktivasyonuna } \\
\text { ve geçici eIF2 } \alpha \text { fosforilasyonuna neden } \\
\text { olmaktadır (Koritzinsky ve ark., 2006). }\end{array}$ \\
\hline Kanser & $\begin{array}{l}\text { Proapoptotik sinyalleri aktive ettiğinden } \\
\text { dolayı PERK ve IRE1 aktivitelerinin } \\
\text { modülasyonu potansiyel kanser tedavisinde } \\
\text { önemli olabilir. (Chakrabarti ve ark., 2011) } \\
\text { UPR indüksiyonu inflamatuar genlerin } \\
\text { ekspresyonlarında artışa neden olmaktadır } \\
\text { (Zhang ve Kaufman, 2008). }\end{array}$ \\
\hline
\end{tabular}

etkilenmemesi için apopitozise yönlendirilir. UPR sonucunda pro-apopitotik CCAAT/enhance binding protein $(\mathrm{C} / \mathrm{EBP})$ homolog protein (CHOP)'nin da rol aldığı mekanizmalarla hücre ölümü gerçekleşir (Shen ve Zhang, 2004). UPR'yi en iyi gösteren genler CHOP, Grp78, Grp94, fare tümör hücresi DNAJ proteini (MTJ1) ve hem oksijenaz 1 (HMOX1)'dir. Bu genlerin ekspresyonlarının tesbiti ile hücredeki strese cevap monitorize edilebilmektedir.

Bütün bu bilgilerin 1şı̆̆ında, çeşitli hastalıkların patofizyolojisinde, UPR yolaklarının ve UPR ile ilişkili genlerin rol oynadığı açıkça görülmektedir. Hücrede ER strese ve UPR aktivasyonuna yol açan birçok neden gösterilmiş ve araştırılmaya da devam edilmektedir. Özellikle kanser, Parkinson, Alzheimer gibi hastalıkların oluşum mekanizmalarının araştııılmasında UPR ayrıntılı bir şekilde incelenmektedir ve tedavide kullanılabilecek yeni ilaçların bulunmas1 hedeflenmektedir. Kanser tedavisinde, tümör hücrelerinin yüzeyinde eksprese olan Grp78'in hedef alındığı yeni tedavi edici ajanlar geliştirilmesi durumunda normal hücreler etkilenmeden tedavi etkinliği artırlabilecektir (Wu ve ark., 2009). Bütün bu mekanizmaların daha ayrıntılı bir şekilde irdelenmesi ve gerek in vivo gerekse de in vitro birçok çalışmanın yapılması gerekmektedir.

\section{KAYNAKLAR}

Argon, Y., Simen, B.B., 1999. GRP94, an ER chaperone with protein and peptide binding properties. Semin. Cell Dev. Biol. 10, $495-505$.

Bodsch, W., Takahashi, K., Barbier, A., Ophoff, B.G., Hossmann, K.A., 1985. Cerebral protein synthesis and ischemia. Prog. Brain Res. 63, 197-210.

Buck, T.M., Wright C.M., Brodsky, J.L., 2007. The activities and function of molecular chaperones in the endoplasmic reticulum. Semin. Cell Dev. Biol. 18, 751-761.

Calfon, M., Zeng, H., Urano, F., Till, J.H., Hubbard, S.R., Harding, H.P.,Clark, S.G., Ron, D., 2002. IRE1 couples endoplasmic reticulum load to secretory capacity by processing the XBP-1 mRNA. Nature. 415, 92-96.

Chakrabarti, A., Chen, A.W., Varner, J.D., 2011. A review of the mammalian unfolded protein response. Biotechnol. Bioeng.108, $2777-2793$.

Conn, K.J., Gao, W.W., Ullman, M.D., McKeon-O'Malley, C., Eisenhauer, P.B., Fine, R.E., Wells, J.M., 2002. Specific up-regulation of GADD153/CHOP in 1-methyl-4-phenyl-pyridinium-treated SH-SY5Y cells. J.Neurosci Res. 68, 755-760.

Corbett, E.F., Oikawa, K., Francois, P.,Tessier, D.C., Kay, C., Bergeron, J.J.M., Thomas, D.Y., Krause, K.H., Michalak, M., 1999. Ca2+ regulation of interactions between endoplasmic reticulum chaperones. J. Biol. Chem. 274, 6203-6211.

Delepine, M., Nicolino, M., Barrett, T., Golamaully, M., Mark, Lathrop, G., Julier, J., 2000. EIF2AK3, encoding translation initiation factor 2-alpha kinase 3, is mutated in patients with Wolcott-Rallison syndrome. Nat. Genet. 25, 406-409.

Dobson, C.M., Sali A., Karplus, M., 1998. Protein folding: A perspective from theory and experiment. Angew. Chem. Int. Edit. $37,868-893$.

Doutheil, J., Treiman, M., Oschlies, U., Paschen, W., 1999. Recovery of neuronal protein synthesis after irreversible inhibition of the endoplasmic reticulum calcium pump. Cell Calcium. 25, 419-428.

Eikelboom, J.W., Lonn, E., Genest, J., Hankey, G., Yusuf, S., 1999. Homocysteine and cardiovasscular disease: A critical review of the epidemiologic evidence. Ann. Intern. Med. 131, 363-375.

Ellgaard, L., Molinari, M., Helenius, A., 1999. Setting the standards: Quality control in the secretory pathway. Science. 286, 1882-1888.

Fernandez, P.M., Tabbara, S.O., Jacobs, L.K., Manning, F.C.R., Tsangaris, T.N., Schwartz, A.M., Kennedy, K.A., Patierno, S. R., 2000. Overexpression of the glucose-regulated stress gene GRP78 in malignant but not benign human breast lesions. Breast Cancer Res. Treat. 59, $15-26$.

Gass, J.N., Gifford, N.M., Brewer, J.W., 2002. Activation of an unfolded protein response during differentiation of antibody-secreting B cells. J. Biol. Chem. 277, 49047-49054.

Harding, H.P., Ron, D., 2002. Endoplasmic reticulum stres and the development of diabetes. Diabetes. 51, S455-S461.

Harding, H.P., Zhang, Y., Ron, D., 1999. Protein translation and folding are coupled by an endoplasmic-reticulum-resident kinase. Nature. 397 , $271-274$.

Harding, H.P., Zeng, H., Zhang, Y., Jungries, R., Chung, P., Plesken, H., Sabatini, D.D., Ron, D., 2001. Diabetes Mellitus and exocrine pancreatic dysfunction in PERK -/- mice reveals a role for translationl control in secretory cell survival. Mol. Cell. 7, 1153-1163.

Hendershot, L.M., 2004. The ER chaperone BiP is a master regulator of ER function. Mt. Sinai J. Med. 71, 289-297. 
Horwich, A., 2002. Protein aggregation in disease: A role for folding intermediates forming specific multimeric interactions. J. Clin. Invest. 110, 1221-1232.

Hu, B.R., Janelidze, S., Ginsberg, M.D., Busto, R, Perez-Pinzon, M., Sick, T.J., Siesjö, B.K., Liu, C.L., 2001. Protein aggregation after focal brain ischemia and reperfusion. J. Cereb. Blood Flow Metab. 21, 865-875.

Huang, R.F., Huang, S.M., Lin, B.S., Wei, J.S., Liu, T.Z., 2001. Homocysteine thiolactone induces apoptotic DNA damage mediated by increased intracellular hydrogen peroxide and caspase 3 activation in HL-60 cells. Life Sci. 68, 2799-2811.

Iwakoshi, N.N., Lee, A.H., Vallabhajosyula, P., Otipoby, K.L., Rajewsky, K., Glimcher, L.H., 2003. Plasma cell differantiation and the unfolded protein response intersect at the transcription factor XBP-1. Nat. Immunol. 4, 321-329.

Kapoor, A., Sanyal, A.J., 2009. Endoplasmic reticulum stress and the unfolded protein response. Clin. Liver Dis.13, 581-590.

Kaufman, R.J., 1999. Stress signaling from the lumen of the endoplasmic reticulum: Coordination of gene transcriptional and translational controls. Gene. Dev. 13, 1211-1233.

Kaufman, R.J., 2002. Orchestrating the unfolded protein response in health and disease. J. Clin. Invest. 110, 1389-1398.

Koritzinsky, M., Magagnin, M.G., van den Beucken, T., Seigneuric, R., Savelkouls, K., Dostie, J., Pyronnet, S., Kaufman, R.J., Weppler, S.A., Voncken, J.W., Lambin, P., Koumenis, C., Sonenberg, N., Wouters, B.G., 2006. Gene expression during acute and prolonged hypoxia is regulated by distinct mechanisms of translational control. Embo J. 25, 1114-1125.

Koumenis, C., Naczki, C., Koritzinsky, M., Rastani, S., Diehl, A., Sonenberg, N., Koromilas, A., Wouters, B.G., 2002. Regulation of protein synthesis by hypoxia via activation of the endoplasmic reticulum kinase PERK and phosphorylation of the translation initiation factor eIF2alpha. Mol. Cell Biol. 22, 7405-7416.

Lai, E.D., Teodoro, T., Volchuk, A., 2007. Endoplasmic reticulum stress: Signaling the unfolded protein response. Physiology. $22,193-201$.

Lee, A.S., 2007. GRP78 induction in cancer: Therapeutic and prognostic implications. Cancer Res. 67, 3496-3499.

Lee, E., Nichols, P., Spicer, D., Groshen, S., Yu, M.C., Lee, A.S., 2006. GRP78 as a novel predictor of responsiveness to chemotherapy in breast cancer. Cancer Res. 66, 7849-7853.

Little, E., Ramakrishnan, M., Roy, B., Gazit, G., Lee, A.S., 1994. The glucose-regulated proteins (GRP78 and GRP94): Functions, gene regulation, and applications. Crit. Rev. Eukar. Gene . 4,1-18.

Liu, C.Y., Schroder, M., Kaufman R.J., 2000. Ligand-independent dimerization activates the stress response kinases IRE1 and PERK in the lumen of the endoplasmic reticulum. J. Biol. Chem. 275, 24881-24885.

Ma, Y., Hendershot, L.M., 2003. Delineation of a negative feedback regulatory loop that controls protein translation during endoplasmic reticulum stress. J. Biol. Chem. 278, 34864-34873.

Maattanen, P., Gehring, K., Bergeron, J.J., Thomas, D.Y., 2010. Protein quality control in the ER: The recognition of misfolded proteins. Semin. Cell Dev. Biol. 21, 500-511.

Misra, U.K., Deedwania, R., Pizzo, S.V., 2006. Activation and cross-talk between Akt, NF-kappaB, and unfolded protein response signaling in 1-LN prostate cancer cells consequent to ligation of cell surface-associated GRP78. J. Biol. Chem. 281, 13694-13707.

Mori, K., 2000. Tripartite management of unfolded proteins in the endoplasmic reticulum. Cell. 101, 451-454.

Naidoo, N., 2009. ER and aging-Protein folding and the ER stress response. Ageing Res. Rev. 8, 150-159.

Nechushtan, A., Smith, C.L., Hsu, Y.T., Youle, R.J., 1999. Conformation of the Bax C-terminus regulates subcellular location and cell death. Embo J. 18, 2330-2341.

Pollard, M.G., Travers, K.J., Weissman, J.S., 1998. Ero1p: A novel and ubiquitous protein with an essential role in oxidative protein folding in the endoplasmic reticulum. Mol. Cell.1, 171-182.

Outinen, P.A., Sood, S.K., Pfeifer, S.I., Pamidi, S., Podor, T.J., Li, J., Weitz, J.I., Austin, R.C., 1999. Homocysteine-induced endoplasmic reticulum stres and growth arrest leads to spesific changes in gene expression in human vascular endothelial cells. Blood. 94, 959-967.

Reddy, R.K., Mao, C.H., Baumeister, P., Austin, R.C., Kaufman, R.J., Lee, A.S., 2003. Endoplasmic reticulum chaperone protein GRP78 protects cells from apoptosis induced by topoisomerase inhibitors-Role of ATP binding site in suppression of caspase-7 activation. J. Biol. Chem. 278, 20915-20924.

Reimold, A.M., Iwakoshi, N.N., Manis, J., Vallabhajosyula, P., Szomolanyi-Tsuda, E., Gravallese, E.M., Friend, D., Grusby, M.J., Alt, F., Glimcher, L.H., 2001. Plasma cell differentiation requires the transcription factor XBP-1. Nature. 412, 300-307.

Ron, D., 2002. Translational control in the endoplasmic reticulum stress response. J. Clin. Invest. 110, 1383-1388.

Ron, D., Walter, P., 2007. Signal integration in the endoplasmic reticulum unfolded protein response. Nat. Rev. Mol. Cell Biol. 8, $519-529$.

Rutkowski, D.T., Kaufman, R.J., 2004. A trip to the ER: Coping with stress. Trends Cell Biol. 14, 20-28.

Scheuner, D., Song, B., McEwen, E., Liu, C., Laybutt, R., Gillespie, P., Saunders, T., Bonner-Weir, S., Kaufman, R.J., 2001. Translational control is required for the unfolded protein response and in vivo glucose homeostasis. Mol. Cell. 7, 1165-1176.

Schroder, M., Kaufman, R.J., 2005. The mammalian unfolded protein response. Annu. Rev. Biochem. 74, 739-789.

Sevier, C.S., Cuozzo, J.W., Vala, A., Aslund, F., Kaiser, C.A., 2001. A flavoprotein oxidase defines a new endoplasmic reticulum pathway for biosynthetic disulphide bond formation. Nat. Cell Biol. 3, 874-882.

Shen, X., Zhang, K., Kaufman, R.J., 2004. The Unfolded protein response- a stress signaling pathway of the endoplasmic reticulum. J. Chem. Neuroanat. 28, 79-92.

Stevens, F.J., Argon, Y., 1999. Protein folding in the ER. Semin. Cell Dev. Biol. 10, 443-454.

Thilmann, R., Xie, Y., Kleihues, P., Kiessling, M., 1986. Persistent inhibition of protein synthesis preceeds delayed neuronal death in postischemic gerbil hippocampus. Acta Neuropathol. 71, 88-93.

Tu, B.P., Ho-Schleyer, S.C., Travers, K.J., Weissman, J.S., 2000. Biochemical basis of oxidative protein folding in the endoplasmic reticulum. Science. 290, 1571-1574.

Wang, M., Wey, S., Zhang, Y., Ye, R., Lee, A.S., 2009. Role of the unfolded protein response regulator GRP78/BiP in development, cancer, and neurological disorders. Antioxid. Redox Sign. 11, 2307-2316.

Wei, M.C., Zong, W.X., Cheng, E.H., Lindsten, T., Panoutsakopoulou, V., Ross, A.J., Roth, K.A., Mac-Gregor, G.R., Thompson, C.B., Korsmeyer, S.J., 2001. Proapoptotic Bax and Bak: A requisite gateway to mitochondrial dysfunction and death. Science. 292, 727-730.

Wormald, M.R., Dwek, R.A., 1999. Glycoproteins: Glycan presentation and protein-fold stability. Structure Fold. Des. 7, R155-R160.

Yoshida, H., Okada, T., Haze, K., Yanagi, H., Yura, T., Negishi, M., Mori, K., 2001. Endoplasmic reticulum stress-induced formation of transcription factor complex ERSF including NF-Y (CBF) and activating transcription factors 6alpha and 6beta that activates the mammalian unfolded protein response. Mol. Cell Biol. 21, 1239-1248. 
Zhang, K., Kaufman, R.J., 2008. From endoplasmic-reticulum stress to the inflammatory response. Nature. 454, 455-462.

Zhang, C., Cai, Y., Adachi, M.T., Oshiro, S., Aso, T., Kaufman, R.J., Kitajima, S., 2001. Homocysteine induces programmed cell death through activation of the unfolded protein response. J. Biol. Chem. 276, 35867-35874. 